\title{
A. ACCOUNTANCY
}

\section{LEER VAN DE CONTROLE}

\section{Rapport van commissarissen en accountantsverklaring}

Knol, H. D. M. - Schrijver pleit ervoor, dat de accountantsverklaring van een N.V. in verband met de functie van de accountant, t.w. vertrouwensman van het publiek, niet moet steunen op werkzaamheden welke door commissarissen verricht zijn. A IV 3

Maandblad voor Bedrijfsadministratie No. 621, December 1948

\section{B. BEDRIJFSHUISHOUDKUNDE}

\section{a. ALGEMENE BEDRIJPSHUISHOUDKUNDE}

\section{- III. WAARNEMINGSMIDDELEN}

\section{Loonadministratie in een middelgroot bedrijf met premiestelsel}

Groenemans, J. - Beschrijving van de wijze waarop de loonadministratie in een bedrijf, dat voor Nederland als representatief kan gelden, plaats vindt. De vereiste werkzaamheden worden door slechts 4 personen verricht.

$\mathrm{B}$ a III 3

Maandblad voor Bedrijfsadministratie No. 621, December 1948

De geconsolideerde jaarrekening

Ploeg. M. J. van der - De geconsolideerde balans geeft de samenstelling van kapitaal- en vermogenspositie aan van moeder- en dochteronderneming. De debiteurcrediteur verhouding, zowel als de verhouding aandeelhouder-N.V. is hieruit geëlimineerd. Schrijver verduidelijkt zijn bespreking over het karakter van de geconsolideerde balans met een eenvoudig gekozen voorbeeld.

$\mathrm{B}$ a III 3

Maandblad voor Bedrijtsadministratie No. 620, November 1948

\section{LEER VAN DE KOSTPRIJS EN DE PRIJSVORMING}

\section{Critische beschouwingen over de vervangingswaardeleer III}

He n sbergen, H. van - In dit artikel, een vervolg op de beschouwingen in het Maandblad voor Handelswetenschappen en Handelspraktijk van Januari 1948 bespreekt schrijver de vervangingswaardeleer als verklarende waardetheorie en komt tot de voorlopige conclusie dat de "waarden" waartoe de vervangingswaardeleer in bepaalde gevallen besluit, geheel andere grootheden zijn als de waarden der subjectieve waardeleer. Het beroep dat sommige verdedigers der vervangingswaardeleer doen op de subjectieve waardeleer berust volgens schrijver op een misverstand, in de hand gewerkt door verwarrende terminologie.

B a IV 2 Maandblad voor Handelswetenschappen en Handelspraktijk No. 4.

\section{Kostprijsgrafieken}

Februari 1949

Prange. A. J. A. - Aan de hand van enkele grafieken wordt uiteengezet hoe men voor de bepaling van de kostprijs, de efficiency-, de bezettings- en de prijsverschillen dient te berekenen.

B a IV 2 Maandblad voor Bedrijfsadministratie No. 621, December 1948

\section{LEER VAN DE FINANCIERING}

\section{Onbelaste Reservering}

Smits, J. P. H. - Naar aanleiding van de resolutie van 27 Februari 1941 No. 106 , waarbij de mogelijkheid werd geschapen om een onbelaste reserve te vormen voor die onroerende goederen die door oorlogsgeweld verloren gingen, de $\mathrm{zgn}$. vervangingsreserve behandelt schrijver eerst de wijze waarop de resolutie de boekhoudkundige verwerking van een dergelijk geval oplost. Deze methode is echter in strijd met artikel $10,2 \mathrm{e}$ lid van het Besluit I.B. De verbeterde oplossing wordt hier gegeven. 
De claimformule en de theorie van de expansiereserve

Prange, A. J. A. - Korte uiteenzetting van een formule ter berekening van de claimwaarde, waarbij geen rekening wordt gehouden met de winst over het nieuwe vermogen.

$\mathrm{B}$ a V 8

Maandblad voor Bedrijfsadministratie No. 620, November 1948

\section{LEER VAN DE ORGANISATIE.}

\section{Principles of Management}

U $r$ w i c k, L. - The body of knowledge described as management is ill-organised. Some important reasons for this lack are: 1 . uncertainty as to the general nature of this body of knowledge; 2. great confusion in the terminology of the subject; 3 . lack of discrimination and definition in the use of terms as law, principle and so on. These and some other reasons are discussed in this article (11 figures).
B a VI 1
British Management Review Vol. VII. No. 3, 1948

How to plan and run open house

S t a rk, L. M. - A description of the organization of an open house or family day program. The jobs to be done can be classified under the following headings: 1 . promotion; 2. invitations; 3 . plant preparation; 4. the tour; 5 . special displays and features; 6. guides; 7. traffic; 8 . hospitality; 9. special arrangements; 10 . souvenirs; 11 . properties; 12. information and 13. follow-up. Ample discussion of these 13 points. A table is showing the Open House practices in 47 companies.

$\mathrm{B}$ a VI 1 Factory Management and Maintenance, Vol. 107, No. 2, Februari 1949 Verkoopkostenanalyse

Bussel, P. H. M. van - Korte beschouwirg over een studie betreffende de analyse van verkoopkosten, die door het Amerikaanse Department van Handel gepubliceerd werd. Op grond van het gebrek aan efficiency in de distributie beveelt het rapport verschillende methoden ter verbetering aan o.a. de splitsing in functionele of ormanische kosten, het opstellen van standaarden en het vergelijken daarvan met de werkelijkheid, verbetering van de administratieve organisatie en techniek, permanente inventaris etc.

B a VI 9

Maandblad voor Bedrijfsadministratie No. 619. October 1948

Englands lachende Plakatwände

Vog t, R. E. - Grossfirmen in England machen Hand in Hand mit der Regierung Reklame. Drei Bedingungen für ein gutes Plakat. 1. Aufmerksamkeit erregen; 2. Eine gute Stimmung schaffen; 3. Durch einen kurzen prägnanten Slogan den Namen des Produktes einprägen. „Keep smiling” in der Englischen Reklame.

$B$ a VI 11

Needed: A broader concept of marketing research

B lankenship, A. B. - Writer gives a new definition of marketing research: it studies people, the product, the procedures of marketing and figures.
B a VI 12
The Journal of Marketing No. 3. Januari 1949

Opstellen Bedrijfsrecht. De positie van commanditaris en derden bij de conmmanditaire vennootschap

Knol, H. D. M. - Artikel 1672, 2e lid B.W. luidt: het is geoorloofd te bedingen dat alle verliezen bij uitsluiting door één of meer der venmoten zullen worden gedragen. Ondanks de publicatie-plicht hiervan vraagt schrijver zich af of hierdoor het karakter van de C.V. niet verloren gaat. Bij de C.V. is de commanditaris aansprakelijk voor het bedrag, dat hij aan de C.V. ter beschikking stelt. Wanneer deze storting echter het karakter van een geldlening gaat krijgen, vervalt hiermede de waarborg voor de zaakscrediteuren.

B a VI 14

Maandblad voor Bedrijfsadministratie No. 620, November 1948

\section{The Office Manager}

$\mathrm{Stagg}, \mathrm{R}$. G. - The different functions of the office manager are discussed here. Especially the last twenty years, personnel administration is the most important function due to decreasing office production. Writer gives four factors which the manager must take into account: desire for recognition, job satisfaction, salary administration and office atmosphere.

B a VI 16

Noma Forum No. 12, December 1948

\section{Personeeldeskundigen voor de bedrijven}

Sternfeld, L. M. H. - De leidende functies in het bedrijfsleven zijn meestal in handen van hen die wel studie van de techniek doch niet van de mens hebben gemaakt. Schr. constateert een groot gebrek aan opleidingsmogelijkheid voor hen die in het bijzonder de personeelsproblemen en -belangen moeten behartigen. De bestaande opleidingen worden critisch beschouwd waarna schr. de conclusie trekt dat een speciale opleiding noodzakelijk is.

B a VI 16

Organisatie en Efficiency, No. 2, Februari 1949

m a b blz. 94 


\section{Le budget de publicitê}

W olf $\mathrm{f}, \mathrm{W} . \mathrm{H}$. - Différents méthodes de repartir les sommes mises a la disposition: de la publicité. Le fonds publicitaire doit être autonome, seul le chef de publicité doit avoir le droit d en disposer et cest il qui doit décider en fine de la repartition.

$\mathrm{B}$ a VI 18

Documentation Commerciale et Comptable No. 50, Februari 1949

\section{De Inventaris}

S p a a n, J. B. J. - Schr. bespreekt de volgende punten: 1e. de inventaris als sluitstuk op het magazijnbeheer en de contröle daarvan; $2 e$. de inventaris dient voor het bedrijfs-economische jaaroverzicht; $3 \mathrm{e}$. de inventaris dient voor de commerciële balans; 4e. de waarde der goederenvoorraad dient op de fiscale balans volgens de fiscale eisen te worden vermeld. Vervolgens worden verschillende methoden van waardering van de goederenvoorraad nagegaan, t.w. naar aanschafwaarde, volgens het stelsel der ijzeren voorraad en naar vervangingswaarde.

B a VI 20

Het Moderne Bedrijfsleven No. 4, Maart 1949

\section{Techniques for Clerical Cost Reduction}

Peterson, R. L. - A study of the operating cost of a typewriting work station showed that more than $85 \%$ of the cost of the total work station is the operator's salary. It is therefore necessary to obtain increased productivity from clerical workers among others by employing certain techniques as job analysis, office engineering standards, merit rating, skill development and the use of older workers.

B a VI 23

Noma Forum No. 11, November 1948

\section{LEER VAN DE ARBEIDSVOORWAARDEN}

\section{A multiple committee method of merit rating}

Turner, W. D. - The author presents here a method of merit rating which requires committees of two departmental officers each to rate the performances of their own subordinates on the basis of concisely written performance descriptions. Principles which the method embodies and which are essential to sound merit rating in most companies, are discussed in a final portion of the article.

B a VII 1

Personnel No. 3, November 1948

\section{Observations on work adjustment - present and future}

Pfiffner. J. M. - The author points out that the beliefs that repetitive work is a bad thing (per se), that highly intelligent persons should never be employed at monotonous tasks, or that employees generally like te make decisions about their work will not stand up under close scrunity. The author debunks some of our conventional ideas about worker adjustment and advocates an integrated approach to placement problems which will draw on the new discoveries of psychology, the other social sciences, and medicine.

$\mathrm{B}$ a VII 5

Personnel No. 3, November 1948

Film als hulpmiddel bij de tijdstudie

Redactie - Dit artikel is ontleend aan het boek van C.L.M. Kerkhoven „Het tempo van arbeidsverrichtingen in de massaproductie". Opsomming van de voor- en nadelen van de film bij de tijdstudie in vergelijking met andere waarnemingsinstrumenten. Hierna volgt een beschouwing over de problemen die zich bij de opname voordoen en tevens over de voordelen die de filmprojectie bij bewegingsstudies biedt. B a VII 5

Bedrijf en Techniek No. 65, 19 Februari 1949

\section{Bedrijfskadertraining II}

Bos, G. - Schrijver gaat in vervolg op het artikel in het Januari-nummer verder in op de programma s Werkinstructie en Werkverhoudingen zoals deze door het Instituut worden gegeven en kondigt aan dat ook het programma Werkmethoden voor Nederland is beschikbaar gekomen. Enige cijfers omtrent de activiteiten van het Instituut.

B a VII 7

Organisatie en Efficiency No. 2, Februari 1949

\section{b. BIJZONDERE BEDRIJVEN}

\section{TRANSPORT EN ANDERE DIENSTVERLENING}

\section{Het rekeningstelsel bij waterleidingbedrijven}

Du p pen, P. H. - Volgens schr. bezit het huidige rekeningstelsel bij de waterleidingbedrijven een zekere tweeslachtigheid, waardoor noch een specificatie van de kosten naar soort, noch die van de totale kosten over de verschillende bedrijfsafdelingen mogelijk is. Bij de indeling van het rekeningstelsel zal men deze moeten laten samenvallen met de bedrijfsfuncties, opdat men in de administratie de nodige gegevens voor de berekening der kosten kan vinden.

B b VII 10

Financieel Overheidsbeheer No. 1, 15 Januari 1949 